\title{
BARTŁOMIEJ KRZECZEWSKI*
}

\section{ZNACZENIE RYNKU KAPITALOWEGO \\ W KONTEKŚCIE ZMIAN ZACHODZĄCYCH W POLSKIM SEKTORZE OCHRONY ZDROWIA}

\section{Wstęp}

Rosnące koszty działalności medycznej zmuszają podmioty działające $\mathrm{w}$ sektorze ochrony zdrowia do poszukiwania nowych możliwości w zakresie finansowania prowadzonej działalności. Pozyskiwanie kapitału, już nie tylko ze środków publicznych, ale również przy wykorzystaniu innych form finansowania, nabiera coraz większego znaczenia. Gruntowna reforma systemu ochrony zdrowia, która miała miejsce w 1999 roku, wprowadziła do niego wiele elementów rynkowych. Obecnie również dokonywane są przekształcenia, mające na celu dalsze urynkowienie systemu poprzez zwiększenie poziomu konkurencyjności, jak również zmiany w strukturze własnościowej. Rynek kapitałowy oferuje szereg narzędzi pozwalających na pozyskanie środków finansowych. Wzrost znaczenia mechanizmów rynku kapitałowego dla przedsiębiorstw działających w sektorze ochrony zdrowia jest zauważalny również w Polsce.

Celem niniejszego opracowania jest omówienie znaczenia rynku kapitałowego i wskazanie możliwości wykorzystania jego potencjału w perspektywie 2020 roku w kontekście zmian zachodzących w polskim sektorze ochrony zdrowia. Zostały również zaprezentowane bieżące trendy w zakresie wykorzystania narzędzi rynku kapitałowego w tym sektorze.

\section{Zmiany w polskim systemie ochrony zdrowia}

W ostatnich kilkunastu latach zauważalny był znaczący wzrost kosztów ochrony zdrowia ${ }^{1}$. Taka sytuacja wymusza wprowadzanie

Doktorant, asystent, Instytut Finansów, Wydział EkonomicznoSocjologiczny, Uniwersytet Łódzki.

Publikacja współfinansowana ze środków Europejskiego Funduszu Społecznego w ramach Poddziałania 8.2.1 Programu Operacyjnego Kapitał Ludzki, w związku z realizacją Projektu „Doktoranci - Regionalna Inwestycja w Młodych naukowców społeczno-humanistycznych - Akronim D-RIM SH”. 
w tym obszarze ciągłych zmian, które będą przyczyniać się do coraz lepszej alokacji zasobów.

Polski system ochrony zdrowia podlegał wielu przemianom, mającym przyczynić się do jego coraz to bardziej efektywnego funkcjonowania. Reforma z 1999 r. umożliwiła prywatnym świadczeniodawcom udzielanie świadczeń zdrowotnych ze środków publicznych. Ponadto wprowadziła do systemu konkurencję pomiędzy podmiotami udzielającymi świadczeń zdrowotnych, dając pacjentowi pełną swobodę wyboru świadczeniodawcy ${ }^{2}$.

Obecnie wprowadzane zmiany zmierzają do dalszego urynkowienia polskiego systemu ochrony zdrowia. Ich przyczyn można dopatrywać się $\mathrm{W}$ narastającym zadłużeniu publicznych zakładów opieki zdrowotnej. Zjawisko to znajduje swoje podłoże w nieodpowiednim wdrożeniu założeń reformy z 1999 r. Wtedy to zaczął obowiązywać system kontraktowy w obszarze finansowania świadczeń zdrowotnych. Wprowadzenie reformy, w przypadku wielu szpitali, wymusiło ich obligatoryjne przekształcenie w samodzielne publiczne zakłady opieki zdrowotnej, gdyż placówki prowadzone w formie zakładów budżetowych nie mogły być stroną umowy kontraktowej z platnikiem ${ }^{3}$.

Wprowadzane zmiany wymagały menedżerskiego podejścia od kadry zarządzającej, a także odpowiedniego zakresu wiedzy ekonomicznej, znajomości zasad funkcjonowania rynku oraz umiejętności odpowiedniej kooperacji - zarówno z płatnikiem, jak i organem założycielskim. Wiele ze szkoleń przygotowanych dla kadry zarządzającej zakładami opieki zdrowotnej było wprowadzanych zbyt późno lub obejmowały one jedynie nieliczną grupę osób zarządzających krajowymi placówkami ochrony zdrowia. Pośród przyczyn wzrastającego zadłużenia publicznych zakładów opieki zdrowotnej można również wymienić umowy, jakie były zawierane $\mathrm{z}$ dyrektorami placówek medycznych wskutek wprowadzonej reformy, wykluczające skuteczną motywację do działań racjonalizatorskich i efektywności, a mogące wzmocnić w zarządzających poczucie

1 A. Depta, Transformacja współczesnych systemów zdrowotnych w wybranych krajach, [w:] Suchecka J. (red.), Finansowanie ochrony zdrowiaWybrane zagadnienia, Wolters Kluwer, Warszawa 2011, s.53.

2 K. Krajewski-Siuda, P. Romaniuk, Zdrowie publiczne - Stan obecny, reformy ostatnich 20 lat, model docelowy, Instytut Sobieskiego, Warszawa 2011, s. 29.

${ }^{3}$ M. Kachniarz, Komercjalizacja samodzielnego publicznego zakładu opieki zdrowotnej - Kluczowe warunki osiagnięcia sukcesu, Wolters Kluwer, Warszawa 2008, s. 36-37. 
bezkarności. Umowy te były zawierane na okres dziesięciu lat i mogły być zerwane jedynie $\mathrm{w}$ przypadku rażącego naruszenia prawa przez dyrektora placówki ${ }^{4}$.

Wobec powyższych problemów, coraz więcej uwagi zaczęto przykładać do rentowności i skutecznego działania publicznych świadczeniodawców. Znaczną poprawę sytuacji w tym zakresie ma przynieść wprowadzona w 2011 roku Ustawa o działalności leczniczej. Jej skutki będą z pewnością odczuwalne w najbliższych latach.

Wprowadzenie owej ustawy zakłada kilka możliwych scenariuszy w odniesieniu do publicznych świadczeniodawców. Organ założycielski może podjąć decyzję $\mathrm{o}^{5}$ :

- przekształceniu i prowadzeniu placówki przez powołaną spółkę prawa handlowego, w której organ założycielski posiada 100 proc. udziałów,

- przekształceniu placówki i utworzeniu spółki kapitałowej, której część lub całość udziałów zostanie sprzedana inwestorowi zewnętrznemu,

- likwidacji samodzielnego publicznego zakładu opieki zdrowotnej i wydzierżawieniu majątku placówki zewnętrznemu operatorowi,

- pozostawieniu samodzielnego publicznego zakładu opieki zdrowotnej w dotychczasowej formie.

Należy w tym miejscu również nadmienić, iż zgodnie z założeniami ustawy znacznie wzrosła odpowiedzialność organów założycielskich za wyniki finansowe osiągane przez podległe im placówki. W przypadku ujemnego wyniku finansowego danej placówki w roku obrotowym, organ założycielski może pokryć tę stratę $\mathrm{w}$ terminie 3 miesięcy od upływu terminu zatwierdzenia sprawozdania finansowego samodzielnego publicznego zakładu opieki zdrowotnej. W przeciwnym razie ustawa wymusza $\mathrm{w}$ przeciągu 12 miesięcy przekształcenie lub likwidację placówki ${ }^{6}$.

Co prawda ustawa zezwala na pozostawienie samodzielnych publicznych zakładów opieki zdrowotnej w dotychczasowej formie (nie zezwala natomiast na tworzenie nowych sp zoz), jednak w związku z tym, iż w przypadku osiągnięcia ujemnego wyniku finansowego organy założycielskie będą zobowiązane we własnym

\footnotetext{
${ }^{4}$ Ibidem, s. 20-23.

5 S. Pitucha, M. Zabelski, Kiedy przeksztatcić SPZOZ w spółkę?, Pismo Samorządu Terytorialnego „Wspólnota”, nr 31, sierpień 2011.

${ }^{6}$ Ustawa z dnia 15 kwietnia 2011 r. o działalności leczniczej, tj. Dz.U. 2011 nr 112 poz. 654, art. 59.
} 
zakresie pokryć straty takich placówek, wydaje się, że w przypadku większości z nich, zdecydują się one na zmianę formy prawnej.

Ustawa wprowadza ponadto szereg zachęt $\mathrm{w}$ postaci różnego rodzaju umorzeń i dotacji dla organów założycielskich, które do dnia 31 grudnia 2013 roku przekształcą samodzielny publiczny zakład opieki zdrowotnej w spółkę kapitałową ${ }^{7}$.

Przekształcenia będą niosły ze sobą również pewne korzyści w zakresie możliwości świadczenia dodatkowych usług komercyjnych, poza realizacją świadczeń finansowanych $w$ ramach kontraktu z Narodowym Funduszem Zdrowia ${ }^{8}$. Co prawda, świadczenia komercyjne w dalszym ciągu stanowią znikomy odsetek w ogólnej liczbie udzielanych świadczeń zdrowotnych, jednak perspektywy w tym zakresie są obiecujące. W 2010 roku wartość prywatnej służby zdrowia wzrosła o 7 proc., a prognozy mówią o tym, iż tempo wydatków na prywatne usługi za zakresu ochrony zdrowia ma wzrastać szybciej aniżeli tempo wzrostu gospodarki ${ }^{9}$.

W związku z omawianymi zmianami zachodzącymi w sektorze ochrony zdrowia, koniecznym wydaje się zaopatrzenie placówek przekształcanych w spółki prawa handlowego w kapitał na odpowiednio wysokim poziomie ${ }^{10}$.

Mając na uwadze opisane powyżej problemy, potencjał, jaki oferuje rozwinięty rynek kapitałowy, nabiera szczególnego znaczenia dla rozwoju polskiego rynku ochrony zdrowia w perspektywie $2020 \mathrm{r}$.

\section{Rynek kapitałowy i jego podstawowe instrumenty}

Rynek kapitałowy stanowi segment rynku finansowego, obok rynku pieniężnego, rynku instrumentów pochodnych oraz rynku walutowego $^{11}$. Rynek finansowy może być zdefiniowany jako ogół transakcji kupna i sprzedaży, których przedmiotem są instrumenty finansowe mające okres wykupu dłuższy niż rok. Celem emitenta owych instrumentów jest pozyskanie środków finansowych, które

\footnotetext{
7 Szerzej: Ustawa z dnia 15 kwietnia 2011 r. o działalności leczniczej, tj. Dz.U. 2011 nr 112 poz. 654, art. 190-203.

${ }^{8}$ S. Pitucha, M. Zabelski, Kiedy przeksztatcić..., op. cit.

9 A. Kazimierczak, Inwestorzy finansują budowe szpitali, www.parkiet.com /artykul/1056210.html, dostęp na 21.05.2012.

${ }^{10}$ S. Pitucha, M. Zabelski, Kiedy przeksztatcić..., op. cit.

11 K. Jajuga, T. Jajuga, Inwestycje - instrumenty finansowe, aktywa niefinansowe, ryzyko finansowe, inżnieria finansowa, Wydawnictwo Naukowe PWN, Warszawa 2007, s. 22-23.
} 
mogą być przeznaczone na działalność rozwojową ${ }^{12}$. Ryzyko na rynku kapitałowym jest relatywnie wysokie, jednak wiąże się również $\mathrm{z}$ relatywnie wyższymi stopami $z w r o t u^{13}$.

Przedmiotem obrotu na rynku kapitałowym są papiery wartościowe. Można tu wyróżnić papiery udziałowe i dłużne ${ }^{14}$. Te pierwsze stwierdzają prawo własności i nazywane są akcjami. Drugie natomiast potwierdzają powstanie wierzytelności i nazywane są obligacjami $^{15}$.

Posiadacz akcji danej spółki nazywany jest akcjonariuszem. Wraz z objęciem akcji danej spółki staje się jej współwłaścicielem. Warto również dodać, że akcje emitowane są przez spółki akcyjne. W przypadku innych rodzajów spółek kapitałowych może być mowa o emisji udziałów. Pośród instrumentów udziałowych można wyróżnić również instrumenty, które nie wiążą się $\mathrm{z}$ posiadaniem prawa własności w podmiotach gospodarczych. Są to jednostki uczestnictwa w otwartych funduszach inwestycyjnych, certyfikaty inwestycyjne zamkniętych funduszy inwestycyjnych oraz certyfikaty indeksowe ${ }^{16}$.

Jeśli chodzi o obligacje, to są one zaliczane do instrumentów dłużnych. Dłużnikiem jest w tym przypadku emitent, a wierzycielem obligatariusz. Obligacje mogą zostać scharakteryzowane za pomocą kilku parametrów. Należą do nich: wartość nominalna, termin wykupu, stopa oprocentowania, termin płatności odsetek (nazywany również okresem odsetkowym).

Obligacje można dzielić ze względu na różnego rodzaju kryteria. Najczęściej stosowane podziały dotyczą:

- kryterium oprocentowania,

- kryterium emitenta.

Zgodnie z kryterium oprocentowania można wyróżnić obligacje o stałym oprocentowaniu, obligacje o zmiennym oprocentowaniu oraz obligacje zerokuponowe - sprzedawane z dyskontem i charakteryzujące się brakiem płatności odsetkowych. Zgodnie z kryterium emitenta obligacje można podzielić natomiast na obligacje skarbowe, obligacje gmin (nazywane również często obligacjami komunalnymi), obligacje przedsiębiorstw i obligacje banków.

12 W. Dębski, Rynek finansowy $i$ jego mechanizmy - podstawy teorii i praktyki, Wydawnictwo Naukowe PWN, Warszawa 2007, s. 95.

${ }^{13}$ Ibidem, s. 96.

${ }^{14} \mathrm{~K}$. Jajuga, T. Jajuga, Inwestycje..., op. cit., s. 23.

${ }^{15}$ W. Dębski, Rynek finansowy..., op. cit., s. 96.

${ }^{16}$ K. Jajuga, T. Jajuga, Inwestycje..., op. cit., s. 32-33, 36. 
W zależności od emitenta, każda $\mathrm{z}$ wymienionych grup obligacji cechuje się innym poziomem ryzyka ${ }^{17}$.

Warto zaznaczyć, że obligacje uważa się za tańsze źródło pozyskiwania kapitału aniżeli akcje, w związku z występowaniem tzw. tarczy podatkowej. Koszt kapitału uzyskiwany z obligacji jest niższy od kosztu kapitału uzyskiwanego z akcji, gdyż odsetki z tytułu oprocentowania płacone obligatariuszom odpisywane są od podstawy opodatkowania, jako koszty finansowe ${ }^{18}$.

Zarówno akcje, jak i obligacje mogą być emitowane w postaci materialnej, jak również zdematerializowanej. Aktualnie, w związku ze znacznym postępem techniki, większość emitowanych papierów wartościowych ma charakter zdematerializowany ${ }^{19}$.

\section{Wykorzystanie instrumentów rynku kapitałowego w polskim sektorze ochrony zdrowia}

W polskim sektorze ochrony zdrowia można odnaleźć wiele przykładów wykorzystania instrumentów rynku kapitałowego. W związku ze zmianami, jakie dokonują się w ostatnim czasie w sektorze opieki zdrowotnej, można przypuszczać, iż w najbliższych latach przykładów będzie jeszcze więcej.

Poniżej zostały przygotowane syntetyczne zestawienia, zawierające dane dotyczące wybranych spółek działających w polskim sektorze ochrony zdrowia, które w ostatnich latach wykorzystywały możliwości na pozyskiwanie środków finansowych, jakie daje rynek kapitałowy.

Pierwsze zestawienie zawiera charakterystyki spółek, które w ostatnich latach miały swoje debiuty na Giełdzie Papierów Wartościowych w Warszawie (tabela 1).

Tabela 1. Debiuty wybranych spólek sektora medycznego

\begin{tabular}{lccl}
\hline Nazwa emitenta & $\begin{array}{c}\text { Data } \\
\text { debiutu }\end{array}$ & $\begin{array}{c}\text { Wartość } \\
\text { emisji (zl) }\end{array}$ & $\begin{array}{c}\text { Segment } \\
\text { rynku }\end{array}$ \\
\hline $\begin{array}{l}\text { EMC INSTYTUT } \\
\text { MEDYCZNY }\end{array}$ & 2005 & 11400000 & $\begin{array}{l}\text { Rynek główny } \\
\text { GPW }\end{array}$ \\
\hline Ź & & & O
\end{tabular}

Źródło: Opracowanie własne na podstawie: www.gpw.pl, stan na 22.05.2012; www.newconnect.pl, stan na 22.05.2012.

\footnotetext{
${ }^{17}$ K. Jajuga, T. Jajuga, Inwestycje..., op. cit., s. 27-30.

${ }^{18}$ W. Dębski, Rynek finansowy..., op. cit., s. 235.

${ }^{19}$ Ibidem., s. 205, 237.
} 
Tabela 1. Debiuty wybranych spółek...

\begin{tabular}{lccl}
\hline $\begin{array}{c}\text { Nazwa } \\
\text { emitenta }\end{array}$ & $\begin{array}{c}\text { Data } \\
\text { debiutu }\end{array}$ & $\begin{array}{c}\text { Wartość } \\
\text { emisji (zl) }\end{array}$ & \multicolumn{1}{c}{ Segment rynku } \\
\hline ENEL-MED & 2011 & 35500000 & Rynek główny GPW \\
GENOMED & 2011 & 2936039 & $\begin{array}{l}\text { Rynek alternatywny New } \\
\text { Connect }\end{array}$ \\
MABION & 2010 & 22800000 & $\begin{array}{l}\text { Rynek alternatywny New } \\
\text { Connect } \\
\text { Rynek alternatywny New } \\
\text { Connect }\end{array}$ \\
PHARMENA & 2008 & 13630760 & \begin{tabular}{l} 
Rynek główny GPW \\
\hline POLMED
\end{tabular} \\
\hline
\end{tabular}

Źródło: Opracowanie własne na podstawie: www.gpw.pl, stan na 22.05.2012; www.newconnect.pl, stan na 22.05.2012.

Jak widać, spółki z sektora medycznego pozyskują znaczne kwoty na finansowanie działalności rozwojowej za pośrednictwem emisji akcji. EMC Instytut Medyczny SA jest notowana na rynku głównym Giełdy Papierów Wartościowych w Warszawie już od 2005 roku. Firma posiadająca obecnie sieć szpitali i przychodni pozyskała podczas debiutu z rynku prawie 11,5 mln zł. Spółka w dalszym ciągu korzysta z udogodnień, jakie oferuje rynek kapitałowy - w grudniu 2011 roku spółka podjęła decyzję o publicznej ofercie 1,19 mln akcji. Środki pozyskane $\mathrm{z}$ tej emisji miały zostać przeznaczone na rozbudowę szpitala geriatrycznego ${ }^{20}$.

Ciekawie również - spośród spółek z tabeli 1. - przedstawia się sytuacja spółki Enel-Med. W 2011 r. odbył się głośny debiut spółki na GPW. Enel-Med pozyskał wówczas 35,5 mln zł. Pozyskane podczas debiutu środki miały zostać przeznaczone na plan inwestycyjny, zakładający stworzenie i wyposażenie nowego szpitala, rozwój segmentu diagnostyki obrazowej i teleradiologii, rozbudowę sieci ogólnodostępnych przychodni oraz wdrożenie nowego systemu $\mathrm{IT}^{21}$. W kontekście owego debiutu należy zauważyć, iż przez lata Enel-Med. pozostawał firmą rodzinną. Po debiucie na GPW pakiet kontrolny, wynoszący $68,8 \%$ udziału w kapitale spółki, w dalszym ciągu pozostawał $\mathrm{w}$ rękach rodziny Rozwadowskich - założycieli firmy. Warto zaznaczyć, iż w akcjonariacie Enel-Medu ujawnił się również

${ }^{20}$ W. Kuta, Kierunek - szpitale, www.rynekzdrowia.pl/Rynek-Zdrowia/ Kierunek-szpitale,115972.html, dostęp na 23.05.2012.

21 Strona internetowa spółki Enel-Med. SA, www.enel.pl, dostęp na 23.05.2012. 
znaczący akcjonariusz, posiadający ponad 10\% udziałów, jakim jest Generali PTE ${ }^{22}$.

Niewątpliwe godne uwagi są również spółki notowane w obrocie alternatywnym na NewConnect zajmujące się głównie nowoczesnymi technologiami w medycynie. Przykładowo spółka Mabion, specjalizująca się $\mathrm{w}$ biotechnologii medycznej, pozyskała $\mathrm{z}$ rynku $22,8 \mathrm{mln}$ zł.

Warto również zaznaczyć, iż w 2010 r. w ramach rynku NewConnect został utworzony indeks NCX Life Science, dedykowany branży medycznej i biotechnologii. W jego skład wchodzi obecnie 10 spółek reprezentujących tę branżę $e^{23}$.

Drugie zestawienie (tabela 2) dotyczy spółek, które w ostatnich latach wykorzystały obligacje $\mathrm{w}$ ramach rynku alternatywnego Catalyst celem finansowania swojego rozwoju.

Tabela 2. Emisje obligacji wybranych spółek sektora medycznego

\begin{tabular}{ccc}
\hline Nazwa emitenta & Data emisji & Wartość emisji (zl) \\
\hline ELECTUS & 2009 & 25767000 \\
IMPOMED & 2010 & 1050000 \\
PCZ & 2011 & 5000000 \\
\hline
\end{tabular}

Źródło: opracowanie własne na podstawie www.gpwcatalyst.pl, stan na dzień 22.05.2012.

Spółka Electus, specjalizująca się w usługach finansowych dla sektora ochrony zdrowia, swoje obligacje emitowała dwukrotnie w 2009 roku. Wartość pierwszej emisji wyniosła 10,133 $\mathrm{mln}$ zl, natomiast drugiej 15,634 mln zł, co dało łączną wartość niemal $26 \mathrm{mln}$ zł.

W 2010 roku swoje obligacje za pośrednictwem rynku Catalyst o wartości przeszło $1 \mathrm{mln}$ zł wyemitowała spółka IMC Impomed Centrum SA. Spółka specjalizuje się głównie w produkcji oraz dystrybucji różnego rodzaju instrumentów i akcesoriów medycznych.

W 2011 natomiast spółka PCZ SA pozyskała poprzez emisję obligacji $5 \mathrm{mln}$ zł. Zgodnie z planem środki w tym przypadku miały zostać przeznaczone na modernizację i budowę nowych obiektów medycznych $^{24}$.

\footnotetext{
${ }^{22}$ W. Kuta, Kierunek..., op. cit.

${ }^{23}$ www.newconnect.pl, dostęp na 22.05.2012.

${ }^{24}$ Medicalnet - Portal Rynku Medycznego, PCZ SA debiut na rynku Catalyst, www.medicalnet.pl, dostęp na 24.05.2012.
} 
Przedstawione powyżej zestawienia nie obejmują oczywiście wszystkich spółek kapitałowych działających w sektorze ochrony zdrowia. Warto by tu chociaż wymienić pozostałe spółki ze wspomnianego indeksu NCX Life Science, jak na przykład Selvita, Blirt, czy Biomed-Lublin Wytwórnia Surowic i Szczepionek. Należy również zauważyć, iż wiele spółek $\mathrm{z}$ sektora ochrony zdrowia pozyskuje kapitał poprzez emisje niepubliczne. Jako przykład można tu przywołać wspomniany już EMC Instytut Medyczny SA, który w 2009 roku dokonał niepublicznej emisji obligacji zwykłych na okaziciela $^{25}$. Innym przykładem może być również Magellan Sp. zo. o., świadcząca usługi finansowe dla sektora medycznego. W 2011 roku spółka dokonała emisji obligacji o wartości ponad $300 \mathrm{mln}$ zł. Należy również zauważyć, iż nie była to pierwsza emisja obligacji tej spółki ${ }^{26}$.

\section{Podsumowanie}

Liczne przykłady wykorzystania możliwości, jakie daje emisja akcji, czy obligacji wskazują na fakt, iż wykorzystanie rynku kapitałowego przez polskie spółki z sektora ochrony zdrowia znajduje się już na zaawansowanym poziomie. Widać, iż już teraz finansowanie rozwoju za pomocą rynku kapitałowego stanowi dla wielu spółek działających w branży medycznej atrakcyjną formę pozyskiwania kapitału w stosunku do tradycyjnych kredytów bankowych. Nie bez znaczenia pozostaje fakt, iż spółki z branży medycznej cieszą się zainteresowaniem inwestorów ze względu na to, że są zaliczane do tzw. firm defensywnych - czyli takich, które radzą sobie lepiej również $\mathrm{w}$ czasach dekoniunktury ${ }^{27}$. Wartym podkreślenia jest również, iż w ostatnim czasie powstały nowe fundusze specjalizujące się $\mathrm{w}$ inwestycjach na polskim rynku usług medycznych, takie jak Ascendis FIZ InMedica ${ }^{28}$.

Zaprezentowane $\mathrm{w}$ przedstawionych wcześniej zestawieniach kwoty uzyskiwane przez spółki za pośrednictwem rynku kapitałowego pokazują jak ważnym jest on narzędziem w finansowaniu działalności

${ }^{25}$ www.mystock.pl, dostęp na 23.05.2012.

26 K. Gemra, Magellan planuje kolejna emisje obligacji, http://wiadomosci.stockwatch.pl/magellan-planuje-kolejna-emisje-obligacji, akcje,15335, dostęp na 23.05.2012.

${ }^{27}$ W. Kuta, Kierunek..., op. cit.

${ }^{28}$ Bankier.pl Polski Portal Finansowy, Polski rynek medyczny atrakcyjny dla inwestorów, www.bankier.pl/wiadomosc/Polski-rynek-medyczny-atrakcyjnydla-inwestorow-2374893.html, dostęp na 24.05.2012. 
rozwojowej i inwestycyjnej spółek z branży medycznej (tabela 1), (tabela 2). Wydaje się, iż sytuacja ta w perspektywie 2020 roku może zostać jeszcze wzmocniona, w związku ze zmianami wprowadzanymi w polskiej ochronie zdrowia. Możliwość przekształceń samodzielnych publicznych zakładów opieki zdrowotnej w spółki prawa handlowego przyczyni się do ułatwienia wykorzystania możliwości, jakie daje rynek kapitałowy. W najbliższych latach będzie prawdopodobnie zauważalny wzmożony proces przekształceń. Będą do nich $\mathrm{z}$ pewnością skłaniały opisane $\mathrm{w}$ artykule czynniki. Podmioty lecznicze będą potrzebowały coraz większych kapitałów, nie tylko ze względu na rosnące koszty opieki medycznej, ale także ze względu na prognozowany na najbliższe lata wzrost znaczenia prywatnych świadczeń zdrowotnych. Tu $\mathrm{z}$ pomocą przyjdą prawdopodobnie instrumenty rynku kapitałowego.

Niewątpliwie, umiejętne wykorzystanie przez firmy z branży medycznej potencjału, jaki oferuje rynek kapitałowy, może przyczynić się W perspektywie 2020 roku do poprawy sytuacji w zakresie lepszego i bardziej elastycznego finansowania działalności inwestycyjnej i rozwojowej $\mathrm{w}$ ochronie zdrowia, poprawy sytuacji w zakresie zadłużenia placówek medycznych, jak również do dalszego rozwoju rynku kapitałowego w Polsce.

\section{Bibliografia}

1. Ustawa z dnia 15 kwietnia 2011 r. o działalności leczniczej, tj. Dz.U. 2011 nr 112 poz. 654.

2. Bankier.pl Polski Portal Finansowy, Polski rynek medyczny atrakcyjny dla inwestorów, www.bankier.pl/wiadomosc/Polskirynek-medyczny-atrakcyjny-dla-inwestorow-2374893.html.

3. Depta A., Transformacja współczesnych systemów zdrowotnych w wybranych krajach, [w:] Suchecka J. (red.), Finansowanie ochrony zdrowia - Wybrane zagadnienia, Wolters Kluwer, Warszawa 2011

4. Dębski W., Rynek finansowy i jego mechanizmy - podstawy teorii i praktyki, Wydawnictwo Naukowe PWN, Warszawa 2007.

5. Gemra K., Magellan planuje kolejna emisje obligacji, http://wiadomosci.stockwatch.pl/magellan-planuje-kolejna-emisjeobligacji,akcje, 15335.

6. Jajuga K., Jajuga T., Inwestycje - instrumenty finansowe, aktywa niefinansowe, ryzyko finansowe, inzynieria finansowa, Wydawnictwo Naukowe PWN, Warszawa 2007. 
7. Kachniarz M., Komercjalizacja samodzielnego publicznego zakładu opieki zdrowotnej - Kluczowe warunki osiagnięcia sukcesu, Wolters Kluwer, Warszawa 2008.

8. Kazimierczak A., Inwestorzy finansuja budowe szpitali, www.parkiet.com /artykul/1056210.html.

9. Krajewski-Siuda K., Romaniuk P., Zdrowie publiczne - Stan obecny, reformy ostatnich 20 lat, model docelowy, Instytut Sobieskiego, Warszawa 2011.

10. Kuta W., Kierunek - szpitale, www.rynekzdrowia.pl/RynekZdrowia/ Kierunek-szpitale, 115972.html.

11. Medicalnet - Portal Rynku Medycznego, PCZ SA debiut na rynku Catalyst, www.medicalnet.pl.

12. Pitucha S., Zabelski M., Kiedy przeksztatcić SPZOZ w spółkę?, Pismo Samorządu Terytorialnego „Wspólnota”, nr 31, sierpień 2011.

\section{Strony internetowe}

1. www.enel.pl.

2. www.gpw.com.pl.

3. www.gpwcatalyst.com.pl.

4. www.mystock.pl.

5. www.newconnect.pl.

\section{Streszczenie}

Ze względu na rosnące koszty działania dostarczyciele usług medycznych $\mathrm{w}$ Polsce zmuszeni są poszukiwać nowych możliwości finansowania działalności. $\mathrm{W}$ artykule wskazano na rosnące znaczenie rynku kapitałowego w finansowaniu działalności placówek medycznych. Głównym celem pracy było wskazanie potencjału instrumentów rynku kapitałowego w finansowaniu działania dostarczycieli usług medycznych w Polsce.

\section{Summary}

\section{THE IMPORTANCE OF CAPITAL MARKET IN FINANCING HEALTHCARE IN POLAND IN THE CONTEXT OF CHANGES OF HEALTH SYSTEM}

Because of growing costs, healthcare providers in Poland are forced to looking for new ways of financing their activity. The article shows the growing importance of capital market as an alternative source for funding their activity. The main aim of the article is to point out the potential that is offered by the capital market instruments. 
Projekt „Doktoranci-Regionalna Inwestycja w Młodych naukowców społeczno-humanistycznych-Akronim D-RIM SH" jest wspólfinansowany przez Unię Europejska ze środków Europejskiego Funduszu Społecznego w ramach Programu Operacyjnego Kapitał Ludzki, Poddziałanie 8.2.1. 